\title{
First Subject In Date Time
}

National Cancer Institute

\section{Source}

National Cancer Institute. First Subject In Date Time. NCI Thesaurus. Code C142558.

The date and time when the first individual is enrolled into a clinical study. 